\title{
A COMPREHENSIVE BEHAVIOURAL ASSESSMENT OF CURCUMIN'S EFFECT ON INFLAMMATORY AND NON-INFLAMMATORY PAIN IN MICE
}

\author{
IOANA-DANA ALEXA ${ }^{1}$, ADINA CARMEN ILIE ${ }^{1}$, GABRIEL PRADA ${ }^{2}$, ANNA MARIE \\ HERGHELEGIU $^{2}$, ANDREI LUCA ${ }^{3}$, TUDOR ȘTEFAN ROTARU ${ }^{4}$, ANDREI DONDAS $^{3}$, \\ GABRIELA RUSU-ZOTA ${ }^{5}$, TEODORA ALEXA-STRATULAT ${ }^{3 *}$, CĂTĂLINA-ROXANA \\ BOHOTIN $^{3}$
}

\author{
${ }^{1}$ Geriatrics Department, “Gr. T. Popa” University of Medicine and Pharmacy, 16 Universității Street, 700021, Iași, Romania \\ 2 "Ana Aslan” National Institute of Gerontology and Geriatrics, "Carol Davila” University of Medicine and Pharmacy, \\ Bucharest, Romania \\ ${ }^{3}$ Advanced Research and Development Centre for Experimental Medicine (CEMEX), "Gr. T. Popa " University of Medicine \\ and Pharmacy, 16 Universității Street, 700021, Iași, Romania \\ ${ }^{4}$ Medical Sciences III Department, "Gr. T. Popa” University of Medicine and Pharmacy, 16 Universității Street, 700021, \\ Iași, Romania \\ ${ }^{5}$ Pharmacology Department, “Gr. T. Popa” University of Medicine and Pharmacy, 16 Universității Street, 700021, Iași, \\ Romania
}

*corresponding author: teodora.alexa-stratulat@umfiasi.ro

Manuscript received: December 2019

\begin{abstract}
The present study aimed to assess the effect of oral curcumin administration on different types of experimental pain and to evaluate its effect on motor activity and coordination. The study was conducted on mice were divided in 4 groups and which received different doses of curcumin through gavage or olive oil (control). Tail Flick, Hot Plate, Rota Rod and Activity Cage tests were performed at baseline and 30,60,120, 180 and 240 minutes after administration. The most efficient dose (120 $\mathrm{mg} / \mathrm{kg} \mathrm{bw}$ ) was chosen for the subsequent assessment. The group that received $120 \mathrm{mg} / \mathrm{kg}$ bw oral curcumin had an increased pain tolerance in both Tail Flick and Hot Plate tests. Curcumin had no effect on paw formalin-induced pain, but significantly decreased the pain-related behaviour in the orofacial formalin-induced pain test and in the visceral pain test. The substance had no influence on motor activity or coordination. Our study proved that curcumin administrated by gavage is effective in nociceptive, visceral and inflammatory experimental pain even after single-dose administration.
\end{abstract}

\section{Rezumat}

Obiectivele studiului au fost evaluarea efectului administrării orale a curcuminei în diferite tipuri de durere experimentală și asupra activității motorii și a coordonării. Șoarecii incluși în studiu au fost împărțiți în 4 grupuri și au primit, prin gavaj, doze diferite de curcumină sau ulei de măsline (control). Testele Tail Flick, Hot Plate, Rota Rod și Activity Cage au fost efectuate atât înainte cât și la 30, 60, 120, 180 și 240 minute după administrare. Doza cea mai eficientă $(120 \mathrm{mg} / \mathrm{kgc})$ a fost aleasă pentru evaluările ulterioare. Grupul care a primit $120 \mathrm{mg} / \mathrm{kgc}$ curcumină orală a avut toleranță crescută la durere, atât la testul Tail Flick, cât și Hot Plate. Curcumina nu a avut nici un efect asupra durerii-induse-de-formalină de la nivelul labei, dar a scăzut semnificativ comportamentul indus de durere, la testul pentru durere orofacială indusă de formalină și testul durerii viscerale. Substanța nu a avut nici o influență asupra activității motorii sau coordonării. Studiul evidențiază faptul că administrarea curcuminei prin gavaj este eficientă în durerea experimentală nociceptivă, viscerală și inflamatorie, chiar după administrarea unei singure doze.

Keywords: analgesia, curcumin, gavage, nociception, inflammation

\section{Introduction}

Curcumin is the main curcuminoid of the spice turmeric, which is widely used in Asian cuisine to add yellow colour, as a flavour, and as a preservative [1]. Currently, it is available as a nutritional supplement and there is no evidence of severe side effects following chronic treatment or large-dose ingestion [2].

In recent years, more and more studies have assessed the potential therapeutic effects of curcumin in several types of conditions. The main mechanisms underlying curcumin's effect seem to be antioxidant and antiinflammatory. Curcumin inhibits enzymes involved in reactive oxygen species (ROS) production [3], decreases myeloperoxidase activity and acts as an independent ROS scavenger [4, 6]. During inflammation, curcumin decreases leucocyte recruitment [5], reduces interleukin and TNF- $\alpha$ production [7], together with decreasing mediators such as phospholipase, lipoxygenase, cyclooxygenase-2, prostaglandins, and nitric oxide [8]. 
The effect of curcumin on pain is still a matter of ongoing research. Its antiinflammatory and anti-oxidant effects have been explored in several clinical trials on post-operative pain and fatigue [9], knee osteoarthritis [10] or chemotherapy-induced neuropathic pain [11] and available results suggest that curcumin is a potent analgesic. However, these trials only investigated chronic curcumin treatment and have not assessed its effect on acute pain. Furthermore, the effects of curcumin on nociception and visceral pain are less known and most available data comes from intraperitoneal administration of curcumin, a route that is not usually applicable in the clinical practice. Curcumin has a poor oral bioavailability, most likely due to its hydrophobic nature and reduced digestive absorption [12]. However, in clinical practice, oral treatment remains the route of administration associated with the highest compliance. The aim of this study was to assess the effect of oral curcumin administration on different types of experimental pain (inflammatory, visceral and nociceptive) and to evaluate the drug's effect on motor activity and coordination.

\section{Materials and Methods}

\section{Animals}

The experiments were conducted on male BALB/c mice (28 - $34 \mathrm{~g}$ ) housed in cages under a 12-h light/dark cycle, with free access to food and water. All animals were habituated to the testing room prior to experiments; the experimental protocol was approved by the ethics committee of the "Gr. T. Popa" University of Medicine and Pharmacy, Iaşi, Romania. All procedures complied with the European Communities Council Directive 2010/63/EU and followed the recommendations of the NIH Guide for the Care and the Use of Laboratory Animals.

The drugs used in the experiment were: $37 \%$ formaldehyde (Fluka, Germany), acetic acid (Sigma, Germany) and curcumin (Curcuma longa (Turmeric), powder, Sigma, Germany).

Nociceptive Models

The Tail Flick test was performed following the method described by D'Amour and Smith [13]. The distal part of the tail was placed on the heat source of the Tail Flick unit (37360 UgoBasile) and the time until the animal removed it away from the heat was recorded.

The Hot Plate test was performed following the method described by Woolfe \& MacDonald [14]. The mice were placed on the hot-plate device maintained at $55 \pm 1^{\circ} \mathrm{C}$ (model-DS 37, UgoBasile) and the time to the first nociceptive response (licking, shaking of hind paws or jumping off the surface) was recorded.

\section{Locomotor Activity Assessment}

In order to assess spontaneous motor activity, an automatic recording system (Activity Cage 7420, Ugo Basile, Italy) was used. Mice were placed in an acrylic rectangular cage with horizontal and vertical infrared sensors and the number of horizontal and vertical movements over a three-minute interval was recorded. Formalin-induced Experimental Pain

Both orofacial and paw formalin tests were performed as described previously [15]. Mice were acclimatized before the test, after which $20 \mu \mathrm{L} \mathrm{5 \%}$ diluted formalin were injected subcutaneously either in the plantar surface of the right hind paw (paw formalin test - PFT) or in the right whisker pad (orofacial formalin test OFT) with a micro syringe. After injection, the animals were placed in an acrylic test box for a $45 \mathrm{~min}$ observation period, during which the number of seconds spent expressing pain-related behaviour was counted. The Acetic Acid Induced Writhing Test (Visceral pain) was performed as described previously [16]. Mice were acclimatized in an acrylic chamber for 20 minutes. Afterwards, they each received $0.1 \mathrm{~mL} / 10 \mathrm{mg}$ bw i.p. $1 \%$ acetic acid and the number of stretches was counted over a 30-minute interval. We defined a stretch as a contraction of the abdominal muscles accompanied by an extension of the forelimbs and elongation of the body.

Study Design

Mice were divided in four acute groups (8 mice/group): three of the groups received different doses of curcumin through gavage $(60 \mathrm{mg} / \mathrm{kg}$ bw - group CC60; 120 $\mathrm{mg} / \mathrm{kg}$ bw - group CC120; $300 \mathrm{mg} / \mathrm{kg} \mathrm{bw} \mathrm{-} \mathrm{group}$ $\mathrm{CC} 300)$ and one group received an equivalent volume $(0.2 \mathrm{~mL})$ of olive oil (group C - control). Tail Flick, Hot Plate and Activity Cage assessment were performed at baseline (before curcumin/olive oil administration) and 30, 60, 120, 180 and 240 minutes after. To assess curcumin's antinociceptive effect on inflammatory and visceral pain, two other groups of mice $(n=24$ mice per group) were tested: one group received curcumin $(120 \mathrm{mg} / \mathrm{kg} \mathrm{bw})-\mathrm{CC} 120$ group and the other an equivalent volume of olive oil through gavage - control group. 150 minutes after curcumin/olive oil treatment, every 8 mice, randomly selected, received intraplantar formalin injection, orofacial formalin injection or intraperitoneal acetic acid injection (i.e. for each model of experimental pain there were eight mice for $\mathrm{CC} 120$ group and eight mice for control group).

Data Analysis

Data are expressed as mean \pm SEM. For the Hot Plate and Tail Flick tests, antinociception was quantified as the percentage of maximal possible effect (\%MPE) according to the following formula [17]:

$$
\begin{gathered}
\% \mathrm{MPE}=[(\text { postdrug latency }- \text { predrug latency }) / \\
(\text { cut-off }- \text { predrug latency })] \times 100 .
\end{gathered}
$$

For the formalin and acetic acid induced pain tests, the antinociceptive activity was expressed as percentage of inhibition of nociceptive behaviour (INB) using the formula [15]:

$$
\begin{gathered}
\% \text { INB }=[(\text { mean Control Group - mean Curcumin } \\
\text { Group }) /(\text { mean Control Group })] \times 100 .
\end{gathered}
$$


The statistical assessment was performed by means of SPSS v.20. Paired and unpaired student t test and repeated measures ANOVA were used when appropriate. Post-hoc comparisons were performed by using the Bonferoni test. The significance level was set at < 0.05 .

\section{Results and Discussion}

The effect of curcumin on nociception

Regarding the Tail Flick test, there were no significant between-group differences at baseline. After $30 \mathrm{~min}$, there was a significant increase in tail flick latency in the CC120 group while latencies remained similar to baseline in all other groups (Figure 1). The antinociceptive effect of the $120 \mathrm{mg} / \mathrm{kg}$ bw curcumin dose persisted for three hours, with means of $6.61 \pm$ $0.50 \mathrm{~s}$ in the CC120 group vs. $5.36 \pm 0.40 \mathrm{~s}$ in the control group at this time point (Figure 1). The MPE in the $\mathrm{CC} 120$ group was $27.50 \%$ (at 60 minutes), with $\mathrm{p}<0.005$ at this time point.

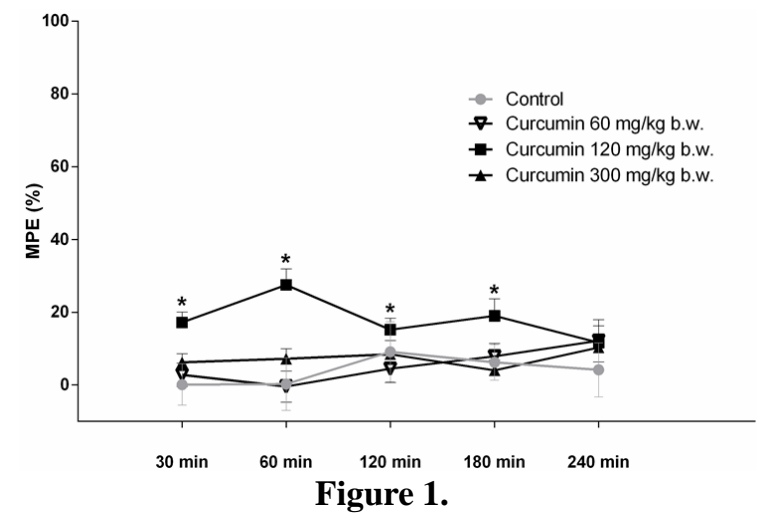

Tail Flick latency (mean \pm SEM) throughout the experiment in the control and curcumin groups $*=\mathrm{p}<0.05$ versus the other groups; MPE - maximal possible effect (\%)

There was no significant difference between groups in the Hot Plate latency at baseline. Although MPEs were positive throughout the experiment for all curcumintreated groups, a clear antinociceptive effect on the Hot Plate test was visible only for the CC120 group at 180 and 240 minutes after administration. At these time points average values were $10.42 \pm 1.19 \mathrm{~s}$ and $10.67 \pm 1.35 \mathrm{~s}$ in the CC120 group vs. $6.83 \pm 0.55 \mathrm{~s}$ and $6.56 \pm 0.67 \mathrm{~s}$ in the control group (Figure 2). Average MPEs in the CC120 group exceed 50\% at both time points. ANOVA two-way assessment identified a significant time-substance interaction for the Hot Plate test, with a p value of 0.006 .

After analysing the results in the Hot Plate and the Tail Flick test, we decided that the optimal curcumin dose for experimental pain tests is $120 \mathrm{mg} / \mathrm{kg}$ bw, since it was the only effective dose in non-neuropathic mice. Also, due to the results that showed an antinociceptive effect in the first three hours in the Tail Flick test and in the last two hours in the Hot Plate test, we decided to perform all pain tests 150 minutes after curcumin gavage.

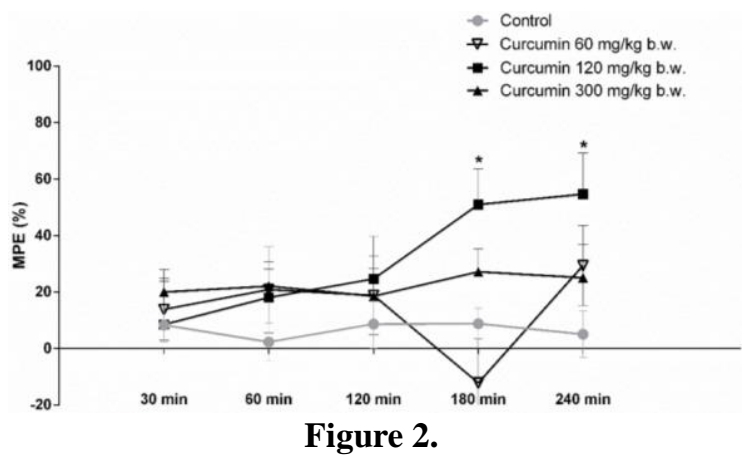

Hot Plate latency (mean \pm SEM) throughout the experiment in the control and curcumin groups $*=\mathrm{p}<0.05$ versus the other groups; MPE - maximal possible effect (\%)

The effect of curcumin on locomotor activity All groups were similar in terms of spontaneous locomotor activity at baseline. However, there was a decrease of both horizontal and vertical movements similar in all curcumin and control groups that corresponded to a statistically significant time effect ( $\mathrm{p}<0.0001$ for both horizontal and vertical movements). The effect of curcumin on experimental pain

There were no significant differences between painrelated behaviours in the two groups in the paw formalin test. Average values were $90.13 \pm 8.29 \mathrm{~s}$ in the control group and $92.25 \pm 9.02 \mathrm{~s}$ in the CC120 group for the first phase of the test $(\mathrm{p}=0.86)$ and $109.0 \pm 22.29 \mathrm{~s}$ in the control group and $109.4 \pm 18.52 \mathrm{~s}$ in the $\mathrm{CC} 120$ group $(\mathrm{p}=0.98)$ for the second phase of the test. For this test, the INB was $-2.35 \%$ for phase I and $-0.36 \%$ for phase II.

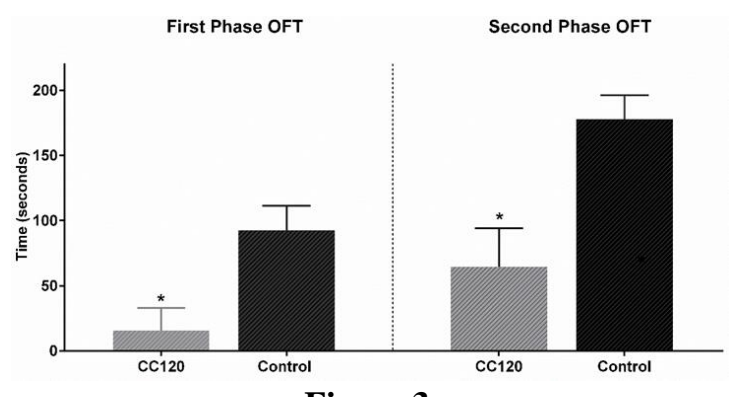

Figure 3.

Time spent expressing pain-related behaviours in the orofacial formalin test in the two groups (mean \pm SEM);

$$
*=\mathrm{p}<0.05
$$

In the first phase of the orofacial formalin test, curcumin induced statistically significant antinociception, with an average of $92.50 \pm 6.69 \mathrm{~s}$ in the control group $v s$. $15.63 \pm 6.10 \mathrm{~s}$ in the CC120 group ( $<$ 0.0001). In the second phase, the difference remained statistically significant $(\mathrm{p}=0.0001)$, with averages of $177.9 \pm 18.54 \mathrm{~s}$ 
in the control group vs. $64.38 \pm 10.57 \mathrm{~s}$ in the $\mathrm{CC} 120$ group (Figure 3 ). For this test, INB was $83.13 \%$ for phase I and $63.81 \%$ for phase II.

Regarding visceral experimental pain, in the CC120 group, the average number of writhes was $36.63 \pm$ 12.34 , whereas in the control group, the average was $108.0 \pm 12.40$. This difference was statistically significant, with a $\mathrm{p}$ value of 0.0013 . The INB for the acetic acid induced writhing test was $66.08 \%$ (Figure 4).

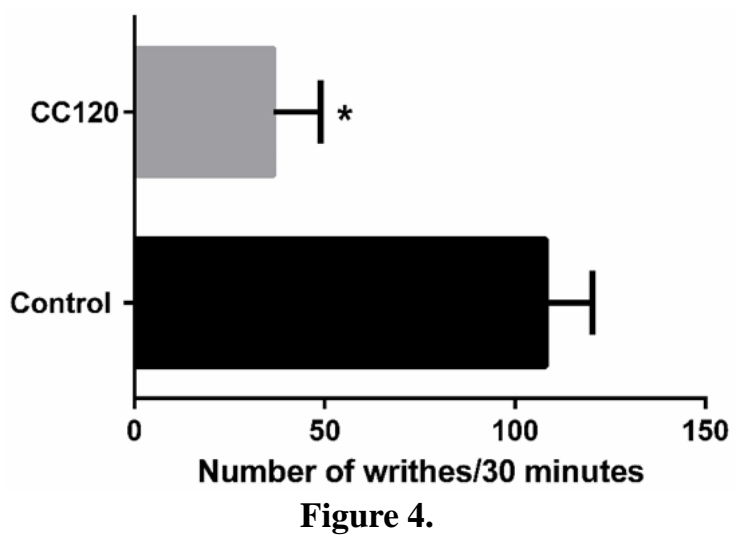

Number of writhes (mean \pm SEM) in the two groups after acetic acid administration; $*=p<0.05$

Our behavioural study demonstrates that single-dose oral curcumin is effective on thermo-nociception and on inflammatory pain induced by formalin and acetic acid.

In our study, curcumin had an analgesic effect on thermo-nociception only at a dose of $120 \mathrm{mg} / \mathrm{kg}$ bw. The smaller and larger doses had a tendency to increase resistance to experimental pain, but their effect was not statistically significant. It is possible that the smaller dose was too small to generate a significant effect, especially since the low bioavailability of oral curcumin is well-known [18]. The larger dose (300 mg/kg bw) was also inefficient, possibly due to the pro-inflammatory effects of large doses of curcumin [19]; the $300 \mathrm{mg} / \mathrm{kg}$ bw dose administered in our study is approximately 1.7 grams when converted to human equivalent dose $[20,21]$, which is significantly larger than the average doses used in clinical studies.

The dose of $120 \mathrm{mg} / \mathrm{kg}$ bw induced a persistent antinociceptive effect in the Tail Flick test over a 3 hour period with a maximum effect at one hour. The effect of curcumin on spinal pain (as assessed by the Tail Flick test) [22] is similar to available literature data. In one study, a diglutaryl curcumin derivate was more effective than aspirin on the tail flick test and induced a MPE three times higher than our results after three hours [23]. In another animal study, the authors found that $25 \mathrm{mg} / \mathrm{kg}$ bw curcumin prodrug had a pronounced antinociceptive effect as assessed by the tail flick test [22].

In the Hot Plate test, a model for testing analgesics with a supra-spinal effect [22], $120 \mathrm{mg} / \mathrm{kg}$ bw curcumin was associated with analgesia that started only three hours after administration. Our results indicate that curcumin is more potent in alleviating supra-spinal nociception when compared with other available data. However, since other studies [24, 25] used intraperitoneal administration or different types of curcumin, the different nociceptive responses for the Hot Plate test could be the consequence of these factors. Moreover, curcumin's antinociceptive effects on Hot Plate were mostly reported in either diabetic or chronic constriction injury mice, models in which the nerve fibres are damaged, whereas in our study the animals had an intact nervous system.

Curcumin had no influence on spontaneous motor activity as assessed by the Activity Cage. These findings support the idea that our results are evidence of curcumin's antinociceptive effect and not a consequence of motor impairment or coordination abnormalities.

The effect of curcumin on formalin-induced experimental pain

Oral administration of a single dose of curcumin had a significant antinociceptive effect on the formalininduced orofacial pain, but no effect on the plantar pain test.

Our results on the orofacial formalin test are in agreement with previously published data. Even if the dose, route of administration and timing are different between studies, other authors have also shown that curcumin administration [26-28] has an antinociceptive effect on both phases of this test.

Contrary to other studies, we found that curcumin does not influence the intensity of pain-evoked behaviour in the paw formalin test. However, some methodological differences between studies must be mentioned. Thus, Fattori et al. used subcutaneous administration route, the Swiss strain, and a curcumin dose of 10 or 30 $\mathrm{mg} / \mathrm{kg}$ bw administrated 1 hour before the test [29]. Considering another study on orofacial formalin test we found, Han et al. used the intrathecal administration route, Sprague Dawley rats and curcumin that was administrated 10 minutes prior to formalin experimental pain [8].

Studies show that the first 5 minutes of formalininduced pain are a consequence of TRPA1 (transient receptor potential cation channel subfamily $\mathrm{A}$, member 1) receptors which activate specific nociceptors [30], whereas the second phase of the formalin test is related to cytokine production [31]. In recent years, studies have shown that the well-known mechanosensitive TRPV4 (transient receptor potential cation channel subfamily V, member 4) contributes to formalin-induced inflammation secondary to extracellular osmolarity changes, suggesting it is an important endogenous mediator of the neurogenic inflammatory reaction [32]. TRPV4 acts on the trigeminal sensory neurons in the orofacial formalin-induced experimental pain model and plays an important role as a signalling molecule in irritation-evoked trigeminal pain; furthermore, it is 
also expressed in visceral sensory DRG (dorsal root ganglion) neurons involved in visceral hypersensitivity. In 2013, Vandewauw et al., mapped the presence of TRPV4 through ganglia and found a statistically significant variability between anatomically different ganglia with a higher level of TRPV4 in trigeminal ganglia as compared with lumbar DRG [33, 34]. This could explain why in our study single-dose curcumin oral administration had an analgesic effect only in the orofacial formalin test, with no effect on the paw formalin test.

The effect of curcumin on visceral experimental pain The acetic acid-induced abdominal pain model is a sensitive test that detects the analgesic effect of substances or doses that may appear ineffective in other pain models. In our study, single-dose oral curcumin administration induced a statistically significant decrease in the number of writhes proving a clear-cut antinociceptive effect for curcumin. To our knowledge, this is the first study to report the effect of oral singledose curcumin administration in the visceral pain test. Our results are in agreement with other studies [29, 35] assessing visceral experimental pain, although the authors used non-oral routes of administration.

Although there are several studies assessing the effects of curcumin on different conditions, available results are heterogeneous due the use of different doses or routes of administration, distinct methods of curcumin preparation and various animal species/strains. All these differences hinder the possibility of a head-to-head comparison. In our study, by using only one route of administration in all models of inflammatory experimental pain and thermo-nociception, we demonstrated that at the same dose the paw formalin test is less sensitive to curcumin's effects when compared with the orofacial formalin test and visceral pain test and that the smaller, as well as the larger doses do not work better on thermo-nociception.

Limits of the study

The main limitations of the study are the fact that not all types of pain were assessed (we did not assess the effect of curcumin on neuropathic pain) and that its design is purely behavioural.

\section{Conclusions}

Although its effects on inflammatory and neuropathic pain are well-known and currently investigated in clinical trials, the effect of curcumin should be explored in other types of pain as well. Our study showed that curcumin is effective in both nociceptive and inflammatory experimental pain even after single-dose oral administration. Preclinical studies in the field should focus on the effect of orally-administered curcumin in order for their results to be transferred to clinical practice more quickly.

\section{Acknowledgement}

This study was supported by a grant from the Romanian National Authority for Scientific Research (CNCS UEFISCDI), project number PN-II-ID-PCE-20113-273.

\section{Conflict of interest}

The authors declare no conflict of interest.

\section{References}

1. Patcharatrakul T, Gonlachanvit S, Chili Peppers, Curcumins, and Prebiotics in Gastrointestinal Health and Disease. Curr Gastroenterol Rep., 2016; 18(4): 19.

2. Belcaro G, Hosoi M, Pellegrini L, Appendino G, Ippolito E, Ricci A, Ledda A, Dugall M, Cesarone MR, Maione C, Ciammaichella G, Genovesi D, Togni S, A controlled study of a lecithinized delivery system of curcumin $\left(\right.$ Meriva $\left.^{\circledR}\right)$ to alleviate the adverse effects of cancer treatment. Phytother Res., 2014; 28(3): 444-450.

3. Zhao WC, Zhang B, Liao MJ, Zhang WX, He WY, Wang HB, Yang CX, Curcumin ameliorated diabetic neuropathy partially by inhibition of NADPH oxidase mediating oxidative stress in the spinal cord. Neurosci Lett., 2014; 560: 81-85.

4. Li G, Hao Y, Li S, Lu H, Zhou F, Therapeutic effects of curcumin on mouse ventricular remodelling. Farmacia, 2019; 67(6): 1041-1047.

5. Afrin R, Arumugam S, Rahman A, Wahed MII, Harima M, Suzuki H, Miyashita S, Suzuki K, Yoneyama H, Ueno $\mathrm{K}$, Watanabe K, Curcumin ameliorates liver damage and progression of NASH in NASH-HCC mouse model possibly by modulating HMGB1-NF- $\kappa$ B translocation. Int Immunopharmacol., 2017; 44: 174-182.

6. Herghelegiu AM, Moser A, Prada GI, Born S, Wilhelm M, Stuck AE, Effects of health risk assessment and counselling on physical activity in older people: A pragmatic randomised trial. PLoS One, 2017; 12(7): e0181371: 1-16.

7. Liang G, Zhou H, Wang Y, Gurley EC, Feng B, Chen L, Xiao J, Yang S, Li X, Inhibition of LPS-induced production of inflammatory factors in the macrophages by mono-carbonyl analogues of curcumin. $J$ Cell Mol Med., 2009; 13(9b): 3370-3379.

8. Han YK, Lee SH, Jeong HJ, Kim MS, Yoon MH, Kim WM, Analgesic effects of intrathecal curcumin in the rat formalin test. Korean J Pain, 2012; 25(1): 1-6.

9. Agarwal KA, Tripathi CD, Agarwal BB, Saluja S, Efficacy of turmeric (curcumin) in pain and postoperative fatigue after laparoscopic cholecystectomy: a doubleblind, randomized placebo-controlled study. Surg Endosc., 2011; 25(12): 3805-3810.

10. Nakagawa Y, Mukai S, Yamada S, Matsuoka M, Tarumi E, Hashimoto T, Tamura C, Imaizumi A, Short-term effects of highly-bioavailable curcumin for treating knee osteoarthritis: a randomized, doubleblind, placebo-controlled prospective study. J Orthop Sci., 2014; 19(6): 933-939.

11. Irving GRB, Iwuji COO, Morgan B, Berry DP, Steward WP, Thomas A, Irving GRB, Brown K, Howells LM, Combining curcumin (C3-complex, Sabinsa) with standard care FOLFOX chemotherapy in patients with inoperable colorectal cancer (CUFOX): study protocol 
for a randomised control trial. Trials, 2015; 16: 110: $1-10$.

12. Sharma RA, Gescher AJ, Steward WP, Curcumin: the story so far. Eur J Cancer, 2005; 41(13): 1955-1968.

13. D'Amour FE, Smith DL, A method for determining loss of pain sensation. J Pharmacol Exp Ther., 1941; 72(1): 74-79.

14. Mungiu CO, Ionescu GD, Diaconescu V, Pain evaluation. Experimental algesiology. Iasi: Polirom; 2001, (available in Romanian).

15. Alexa T, Luca A, Dondas A, Bohotin CR, Preconditioning with cobalt chloride modifies pain perception in mice. Exp Ther Med., 2015; 9(4): 1465-1469.

16. Luca A, Alexa T, Dondaş A, Andron G, Bădescu M, Alexa ID, Bohotin C, Pain modulation by curcumin and ascorbic acid in mice. Rev Medico-Chirurgicală a Soc Medici ş̧i Nat din Iaşı, 2014; 118(2): 346-351.

17. Wang Z, Gardell LR, Ossipov MH, Vanderah TW, Brennan MB, Hochgeschwender U, Hruby VJ, Malan TPJr, Lai J, Porreca F, Pronociceptive actions of dynorphin maintain chronic neuropathic pain. JNeurosci., 2001; 21(5): 1779-1786.

18. Chaurasia S, Patel RR, Chaubey P, Kumar N, Khan G, Mishra B, Lipopolysaccharide based oral nanocarriers for the improvement of bioavailability and anticancer efficacy of curcumin. Carbohydr Polym., 2015; 130: 9-17.

19. Tanwar V, Sachdeva J, Kishore K, Mittal R, Nag TC, Ray R, Kumari S, Arya DS, Dose-dependent actions of curcumin in experimentally induced myocardial necrosis: a biochemical, histopathological, and electron microscopic evidence. Cell Biochem Funct., 2010; 28(1): 74-82.

20. Nair AB, Jacob $S, A$ simple practice guide for dose conversion between animals and human. $J$ basic Clin Pharm., 2016; 7(2): 27-31.

21. Herghelegiu AM, Prada GI, Nacu RM, Prolonged use of protop pump inhibitors and cognitive function in older adults. Farmacia, 2016; 64(2): 262-267.

22. Wongsrisakul J, Wichitnithad W, Rojsitthisak P, Towiwat $\mathrm{P}$, Antinociceptive effects of curcumin diethyl disuccinate in animal models. J Heal Res., 2010; 24(4): 175-180.

23. Jacob JN, Badyal DK, Bala S, Toloue M, Evaluation of the in vivo anti-inflammatory and analgesic and in vitro anti-cancer activities of curcumin and its derivatives. Nat Prod Commun., 2013; 8(3): 359-362.

24. Zhu Q, Sun Y, Yun X, Ou Y, Zhang W, Li JX, Antinociceptive effects of curcumin in a rat model of postoperative pain. Sci Rep., 2014; 4: 4932: 1-4.

25. Banafshe HR, Hamidi GA, Noureddini M, Mirhashemi SM, Mokhtari R, Shoferpour M, Effect of curcumin on diabetic peripheral neuropathic pain: possible involvement of opioid system. Eur J Pharmacol., 2014; 723: 202206.

26. Herghelegiu AM, Nacu RM, Prada GI, Metabolic parameters and cognitive function in a cohort of older diabetic patients. Aging Clin Exp Res., 2016; 28(6): 1105-1112.

27. Mittal N, Joshi R, Hota D, Chakrabarti A, Evaluation of antihyperalgesic effect of curcumin on formalininduced orofacial pain in rat. Phytother Res., 2009; 23(4): 507-512.

28. Yeon KY, Kim SA, Kim YH, Lee MK, Ahn DK, Kim HJ, Kim JS, Jung SJ, Oh SB, Curcumin produces an antihyperalgesic effect via antagonism of TRPV1. J Dent Res., 2010; 89(2): 170-174.

29. Fattori V, Pinho-Ribeiro FA, Borghi SM, Alves-Filho JC, Cunha TM, Cunha FQ, Casagrande R, Verri WAJr, Curcumin inhibits superoxide anion-induced pain-like behavior and leukocyte recruitment by increasing Nrf2 expression and reducing NF- $\mathrm{KB}$ activation. Inflamm Res., 2015; 64(12): 993-1003.

30. McNamara CR, Mandel-Brehm J, Bautista DM, Siemens J, Deranian KL, Zhao M, Hayward NJ, Chong JA, Julius D, Moran MM, Fanger CM, TRPA1 mediates formalin-induced pain. Proc Natl Acad Sci USA, 2007; 104(33): 13525-13530.

31. Chichorro JG, Lorenzetti BB, Zampronio AR, Involvement of bradykinin, cytokines, sympathetic amines and prostaglandins in formalin-induced orofacial nociception in rats. Br J Pharmacol., 2004; 141(7): 1175-1184.

32. Vergnolle N, Cenac N, Altier C, Cellars L, Chapman K, Zamponi GW, Materazzi S, Nassini R, Liedtke W, Cattaruzza F, Grady EF, Geppetti P, Bunnett NW, A role for transient receptor potential vanilloid 4 in tonicity-induced neurogenic inflammation. Br J Pharmacol., 2010; 159: 1161-1173.

33. Vandewauw I, Owsianik G, Voets T, Systematic and quantitative mRNA expression analysis of TRP channel genes at the single trigeminal and dorsal root ganglion level in mouse. BMC Neurosci., 2013; 14: 21: 1-7.

34. Herghelegiu AM, Prada GI, Nacu RM, Kozma A, Alexa ID, Statin Use and risk of sarcopenia in community dwelling older adults. Farmacia, 2018; 66(4): 702-707.

35. Leamy AW, Shukla P, McAlexander MA, Carr MJ, Curcumin ((E,E)-1,7-bis(4-hydroxy-3-methoxyphenyl)1,6-heptadiene-3,5-dione) activates and desensitizes the nociceptor ion channel TRPA1. Neurosci Lett., 2011; 503(3): 157-162. 